\title{
Genetic progress in oat associated with fungicide use in Rio Grande do Sul, Brazil
}

\author{
D.N. Follmann', A. Cargnelutti Filho ${ }^{1}$, A.D. Lúcio ${ }^{1}$, V.Q. de Souza ${ }^{2}$, \\ M. Caraffa ${ }^{3}$ and C.A. Wartha ${ }^{1}$ \\ ${ }^{1}$ Departamento de Fitotecnia, Universidade Federal de Santa Maria, \\ Santa Maria, RS, Brasil \\ ${ }^{2}$ Universidade Federal do Pampa, Dom Pedrito, RS, Brasil \\ ${ }^{3}$ Departamento de Agronomia, Sociedade Educacional Três de Maio, \\ Três de Maio, RS, Brasil \\ Corresponding author: A. Cargnelutti Filho \\ E-mail: alberto.cargnelutti.filho@gmail.com
}

Genet. Mol. Res. 15 (4): gmr15049390

Received September 28, 2016

Accepted November 11, 2016

Published December 19, 2016

DOI http://dx.doi.org/10.4238/gmr15049390

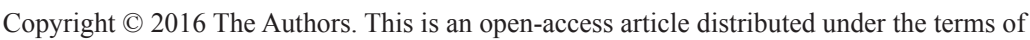
the Creative Commons Attribution ShareAlike (CC BY-SA) 4.0 License.

\begin{abstract}
The State of Rio Grande do Sul(RS) is the largest producer of oat in Brazil with the aid of consolidated breeding programs, which are constantly releasing new cultivars. The main objectives of this study were to: 1) evaluate the annual genetic progress in grain yield and hectoliter weight of the oat cultivars in RS, with and without fungicide use on aerial parts of plants; and 2) evaluate the efficiency of oat breeding programs in introducing disease-resistant genes in the released cultivars through network yield trials conducted with and without fungicide use on aerial plant parts. The data on grain yield and hectoliter weight were obtained from 89 competition field trials of oat cultivars carried out from 2007 to 2014 in nine municipalities of RS. Of the total 89 trials, 44 were carried out with fungicide application on aerial plant parts and
\end{abstract}

Genetics and Molecular Research 15 (4): gmr15049390 
45 were carried out without fungicide application. The annual genetic progress in oat cultivars was studied using the methodology proposed by Vencovsky (1988). The annual genetic progress in oat grain yield was $1.02 \%$ with fungicide use and $4.02 \%$ without fungicide use during the eight-year study period in RS. The annual genetic progress with respect to the hectoliter weight was $0.08 \%$ for trials with fungicide use and $0.71 \%$ for trials without fungicide use. Performing network yield trials with and without fungicide use on the aerial plants parts is a feasible method to evaluate the efficiency of oat breeding programs in introducing disease-resistant genes in the released cultivars.

Key words: Avena sativa L.; Cultivars; Breeding, Genetic gain; Disease resistance

\section{INTRODUCTION}

The oat crop is highlighted with great importance in grain production systems as well as for crop-livestock integration in southern Brazil (Lângaro and Carvalho, 2014). Moreover, it is an economical alternative for winter season and assists in the adoption of no-tillage system of agriculture. The modern oat cultivars released in Brazil are the result of efficient plant breeding programs, which increase the grain quality and yield, and thus support the country in reducing oat importation. In addition, oat cultivation promotes the growth of small-scale processing industries (Federizzi et al., 2005).

The Brazilian oat-cultivated area has progressively increased, with an area of 171,300 ha during the 2013-2014 agricultural year. In this agricultural year, the average grain yield was $2230 \mathrm{~kg} / \mathrm{ha}$, representing an increase of $1.5 \%$ in area and $4.3 \%$ in grain yield over the previous agricultural year. Rio Grande do Sul (RS) stands out as the largest oat-producing state in Brazil, with an oat-cultivated area of 102,500 ha and average grain yield of $2691 \mathrm{~kg} / \mathrm{ha}$ in the 2013-2014 agricultural year (Conab, 2013). Thus, oat has occupied the position of the second most cultivated cereal in southern Brazil (Deuner et al., 2014).

The oat crop (Avena sativa L.) has remained highlighted due to the constant efforts of public and private institutions carrying out plant breeding research. These efforts can be measured by studying genetic progress in the new oat cultivars released in the market. Studying genetic progress is important to evaluate the efficiency of plant breeding programs (Borges et al., 2009). If required, this study can suggest possible changes in the strategies and methodologies used in plant breeding programs (Faria et al., 2007). For the oat crop, the studies developed by Barbosa Neto et al. (2000) in Brazil and by Redaelli et al. (2008) in Italy can be emphasized. In addition, the studies with cereals from the same family as wheat (Nedel, 1994; Rodrigues et al., 2007; Cargnin et al., 2008; Oury et al., 2012; Beche et al., 2014; Thomas and Graf, 2014; Wu et al., 2014), rice (Borges et al., 2009; Breseghello et al., 1999, 2011; DoVale et al., 2012), and popcorn (Ribeiro et al., 2012) can be highlighted.

The use of cultivar competition trials in different locations and years of evaluation in order to estimate the annual genetic progress was proposed by Vencovsky et al. (1988). Genetic progress in cultivars is estimated by replacing the existing cultivars with the supposedly superior

Genetics and Molecular Research 15 (4): gmr15049390 
new cultivars. One of the main advantages of using data from the previously performed field trials is the cost reduction as compared to the other methods (Toledo et al., 1990).

The State of Rio Grande do Sul (RS) has a great potential to increase oat yield. However, leaf diseases, such as leaf rust, have been recognized as potentially aggressive diseases (Chaves and Martinelli, 2005), which reduce the yield and quality of oat grains (Martinelli et al., 2009). Dividing the cultivar trials with and without fungicide use is relevant. In France, different estimates of genetic progress were obtained for wheat cultivars grown with and without fungicide use (Oury et al., 2012). In Brazil, differences in oat trials with and without fungicide use have been reported in the studies of cultivar stability and adaptability (Lorencetti et al., 2004) and stratification of environments (Benin et al., 2005).

The selection criteria have great importance in oat breeding programs, wherein the increased number and quality of grains are prioritized in the final selection for disease resistance. The quantitative traits, such as grain filling duration, hectoliter weight, hull/grain ratio, and industrial yield, can be attributed to grain quality (Federizzi et al., 2005). According to Lângaro and Carvalho (2014), the yield and industrial quality of oat grains play an important role in their commercialization, wherein the industry takes into account the thousand grain weight, hectoliter weight, and the percentage of grains larger than two millimeters.

The introduction of foreign germplasm can benefit oat breeding programs in Brazil, providing a gene pool with new groups of genes and alleles, and hence crops genetic gains (Luche et al., 2013). From the 1970s onwards, several breeding program partnerships were established between the United States and Brazilian research institutions; these programs introduced the sources of resistance mainly to leaf and stem rust in oat (Federizzi et al., 2005). Leaf rust is a major disease of oat (Zambonato et al., 2012), causing reduction in its grain quality (Doehlert et al., 2001). It was assumed that genetic progress in grain yield and hectoliter weight was associated with fungicide use on aerial plant parts of oat cultivars in RS. Thus, the objectives of this study were: 1) to evaluate genetic progress in grain yield and hectoliter weight of oat cultivars in RS, with and without fungicide use on aerial plant parts; and 2) to evaluate the efficiency of oat breeding programs in the introduction of diseaseresistance genes in the released cultivars through network yield trials carried out with and without fungicide use on aerial plant parts.

\section{MATERIAL AND METHODS}

The data of grain yield $(\mathrm{kg} / \mathrm{ha})$ and hectoliter weight $(\mathrm{kg} / 100 \mathrm{~L})$ were obtained from 89 field trials belonging to the competition network of oat cultivars. The field trials were carried out during the period from 2007 to 2014 in nine municipalities of RS (Figure 1). Data were obtained from the annals of the Brazilian Committee of Oat Research meeting (RCBPA), published annually in the Congress of RCBPA (Table 1).

All trials were carried out using the randomized block design with three replications. The experimental units consisted of five rows with a spacing of 0.17 to 0.20 $\mathrm{m}$. All experimental units were $5.0-\mathrm{m}$ long. The experimental unit area ranged from 4.25 to $5.0 \mathrm{~m}^{2}$. The number of cultivars ranged from 13 to 25 , totaling up to 36 during the entire experimental period (Table 2).

Genetics and Molecular Research 15 (4): gmr15049390 


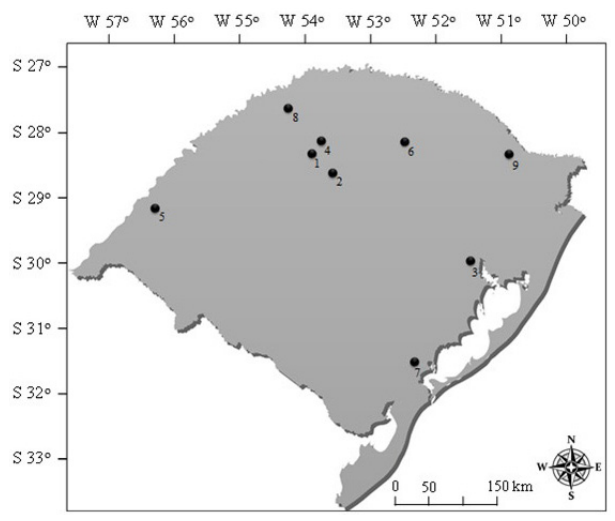

Figure 1. Geographical representation of the nine locations where the oat trials organized by the Brazilian Committee of Oat Research were carried out in Rio Grande do Sul, Brazil, during the period from 2007 to 2014 . 1 $=$ Augusto Pestana; $2=$ Cruz Alta; $3=$ Eldorado do Sul; $4=$ Ijuí; $5=$ Itaqui; $6=$ Passo Fundo; $7=$ Pelotas; $8=$ Três de Maio; 9 = Vacaria.

Table 1. Chronological list of the scientific studies from the Brazilian Committee of Oat Research meeting used in this study.

\begin{tabular}{|c|c|c|c|c|c|}
\hline \multirow[t]{2}{*}{ Summary } & \multirow[t]{2}{*}{ Year } & \multirow[t]{2}{*}{ Main reference } & \multicolumn{2}{|c|}{ Page } & \multirow[t]{2}{*}{ No. of trials } \\
\hline & & & Initial & Final & \\
\hline 1 & 2007 & RCBPA, 2008 & 143 & 146 & 2 \\
\hline 2 & 2007 & RCBPA, 2008 & 159 & 161 & 2 \\
\hline 3 & 2007 & RCBPA, 2008 & 162 & 165 & 2 \\
\hline 4 & 2007 & RCBPA, 2008 & 166 & 168 & 2 \\
\hline 5 & 2007 & RCBPA, 2008 & 185 & 187 & 2 \\
\hline 6 & 2008 & RCBPA, 2009 & 358 & 360 & 2 \\
\hline 7 & 2008 & RCBPA, 2009 & 361 & 362 & 2 \\
\hline 8 & 2008 & RCBPA, 2009 & 363 & 365 & 2 \\
\hline 9 & 2008 & RCBPA, 2009 & 366 & 369 & 2 \\
\hline 10 & 2008 & RCBPA, 2009 & 370 & 377 & 2 \\
\hline 11 & 2008 & RCBPA, 2009 & 401 & 405 & 4 \\
\hline 12 & 2009 & RCBPA, 2010 & 343 & 346 & 2 \\
\hline 13 & 2009 & RCBPA, 2010 & 351 & 354 & 2 \\
\hline 14 & 2009 & RCBPA, 2010 & 357 & 360 & 2 \\
\hline 15 & 2009 & RCBPA, 2010 & 361 & 366 & 2 \\
\hline 16 & 2009 & RCBPA, 2010 & 367 & 369 & 2 \\
\hline 17 & 2009 & RCBPA, 2010 & 370 & 374 & 2 \\
\hline 18 & 2010 & RCBPA, 2011 & 365 & 372 & 2 \\
\hline 19 & 2010 & RCBPA, 2011 & 388 & 392 & 2 \\
\hline 20 & 2010 & RCBPA, 2011 & 393 & 395 & 2 \\
\hline 21 & 2010 & RCBPA, 2011 & 404 & 409 & 2 \\
\hline 22 & 2010 & RCBPA, 2011 & 425 & 429 & 2 \\
\hline 23 & 2011 & RCBPA, 2012 & 1 & 4 & 2 \\
\hline 24 & 2011 & RCBPA, 2012 & 1 & 3 & 2 \\
\hline 25 & 2011 & RCBPA, 2012 & 1 & 9 & 2 \\
\hline 26 & 2011 & RCBPA, 2012 & 1 & 4 & 2 \\
\hline 27 & 2011 & RCBPA, 2012 & 1 & 5 & 2 \\
\hline 28 & 2012 & RCBPA, 2013 & 1 & 4 & 2 \\
\hline 29 & 2012 & RCBPA, 2013 & 1 & 3 & 2 \\
\hline 30 & 2012 & RCBPA, 2013 & 1 & 4 & 2 \\
\hline 31 & 2012 & RCBPA, 2013 & 1 & 4 & 2 \\
\hline 32 & 2012 & RCBPA, 2013 & 1 & 5 & 2 \\
\hline 33 & 2013 & RCBPA, 2014 & 1 & 4 & 2 \\
\hline 34 & 2013 & RCBPA, 2014 & 1 & 3 & 2 \\
\hline 35 & 2013 & RCBPA, 2014 & 1 & 4 & 2 \\
\hline 36 & 2013 & RCBPA, 2014 & 1 & 4 & 1 \\
\hline 37 & 2013 & RCBPA, 2014 & 1 & 4 & 2 \\
\hline 38 & 2013 & RCBPA, 2014 & 1 & 4 & 2 \\
\hline 39 & 2014 & RCBPA, 2015 & 1 & 4 & 2 \\
\hline 40 & 2014 & RCBPA, 2015 & 1 & 3 & 2 \\
\hline 41 & 2014 & RCBPA, 2015 & 1 & 4 & 2 \\
\hline 42 & 2014 & RCBPA, 2015 & 1 & 4 & 2 \\
\hline 43 & 2014 & RCBPA, 2015 & 1 & 33 & 2 \\
\hline 44 & 2014 & RCBPA, 2015 & 1 & 4 & 2 \\
\hline
\end{tabular}

Genetics and Molecular Research 15 (4): gmr15049390 
Table 2. Years, locations, and number of trials and cultivars evaluated in the network of oat cultivars competition trials (Avena sativa L.) from 2007 to 2014 in Rio Grande do Sul (RS), Brazil, with and without fungicide use on aerial plant parts.

\begin{tabular}{|c|c|c|c|c|c|c|c|c|c|c|c|}
\hline \multirow[t]{2}{*}{ Year } & \multicolumn{9}{|c|}{ Locations } & \multirow{2}{*}{$\begin{array}{c}\text { No. of } \\
\text { trials }\end{array}$} & \multirow{2}{*}{$\begin{array}{c}\text { No. of } \\
\text { cultivars }\end{array}$} \\
\hline & Augusto Pestana & Cruz Alta & Eldorado do Sul & Ijuí & Itaqui & Passo Fundo & Pelotas & Três de Maio & Vacaria & & \\
\hline \multicolumn{12}{|c|}{ With fungicide } \\
\hline 2007 & - & 1 & 1 & - & - & 1 & 1 & 1 & - & 5 & 13 \\
\hline 2008 & - & 1 & 1 & 1 & - & 1 & 1 & 1 & 1 & 7 & 14 \\
\hline 2009 & - & - & 1 & 1 & - & 1 & 1 & 1 & 1 & 6 & 18 \\
\hline 2010 & 1 & - & 1 & - & - & 1 & 1 & 1 & - & 5 & 25 \\
\hline 2011 & 1 & - & 1 & - & - & 1 & 1 & 1 & - & 5 & 25 \\
\hline 2012 & 1 & - & 1 & - & - & 1 & 1 & 1 & - & 5 & 25 \\
\hline 2013 & 1 & - & 1 & - & 1 & - & 1 & 1 & - & 5 & 22 \\
\hline 2014 & 1 & - & 1 & - & 1 & 1 & 1 & 1 & - & 6 & 22 \\
\hline \multicolumn{12}{|c|}{ Without fungicide } \\
\hline 2007 & - & 1 & 1 & - & - & 1 & 1 & 1 & - & 5 & 13 \\
\hline 2008 & - & 1 & 1 & 1 & - & 1 & 1 & 1 & 1 & 7 & 14 \\
\hline 2009 & - & - & 1 & 1 & - & 1 & 1 & 1 & 1 & 6 & 18 \\
\hline 2010 & 1 & - & 1 & - & - & 1 & 1 & 1 & - & 5 & 25 \\
\hline 2011 & 1 & - & 1 & - & - & 1 & 1 & 1 & - & 5 & 25 \\
\hline 2012 & 1 & - & 1 & - & - & 1 & 1 & 1 & - & 5 & 25 \\
\hline 2013 & 1 & - & 1 & - & 1 & 1 & 1 & 1 & - & 6 & 22 \\
\hline 2014 & 1 & - & 1 & - & 1 & 1 & 1 & 1 & - & 6 & 22 \\
\hline Total & 10 & 4 & 16 & 4 & 4 & 15 & 16 & 16 & 4 & 89 & 36 \\
\hline
\end{tabular}

Calculation of genetic progress was performed individually for the municipalities of Eldorado do Sul, Passo Fundo, Pelotas, and Três de Maio. The trials were carried out during all years of the study period in these locations. For the calculation of genetic progress in RS, the cultivar trials carried out during the study period in all nine municipalities, including Augusto Pestana, Cruz Alta, Eldorado do Sul, Ijuí, Itaqui, Passo Fundo, Pelotas, Três de Maio, and Vacaria, were considered.

The trials were designed to generate information for recommending cultivars with better performance on exposure to different growing environments. Cultivars with unsatisfactory performance were discarded and replaced by other cultivars with supposedly greater yield potential. Cultivars that exhibited satisfactory performance were maintained for evaluation in the following year.

Genetic progress in oat cultivars was studied using the methodology proposed by Vencovsky et al. (1988), which is based on the data generated in the regional cultivar trials. In addition, genetic gain estimates and genetic progress balance were determined using the method of generalized least squares (Cruz, 2001).

Thus, initially, the rates of included (I), deleted (D), maintained (M), and renewed (R) cultivars in the trials were estimated using the following formulas:

$$
\begin{aligned}
& \% I=\frac{100 I}{M+D+I} \\
& \% \mathrm{D}=\frac{100 D}{M+D+I}
\end{aligned}
$$




$$
\begin{gathered}
\% \mathrm{M}=\frac{100 M}{M+D+I} \\
\% R=\frac{100 I}{M+I}
\end{gathered}
$$

where I is the number of cultivars included in the following year; $\mathrm{D}$ is the number of cultivars deleted in the previous year; $\mathrm{M}$ is the number of cultivars maintained from one year to another; and $\mathrm{R}$ represents the renewal of cultivars (Cruz, 2001).

Subsequently, genetic gain was estimated for every two years, using the linear regression model proposed by Vencovsky et al. (1988):

$$
\hat{G} g=(\bar{y} 2-\bar{y} 1)-(\bar{y} c 2-\bar{y} c 1)
$$

(Equation 5)

where $\hat{\mathrm{G} g}$ is the estimate of genetic gain; $\bar{y} 1$ is the overall mean of cultivars in the year 1 trial; $\bar{y} 2$ is the overall mean of cultivars in the year 2 trial; $\bar{y} \mathrm{c} 1$ is the overall mean of common cultivars in the year 1 trial; and $\bar{y} \mathrm{c} 2$ is the overall mean of common cultivars in the year 2 trial.

In this methodology, the gross difference was obtained by $(\bar{y} 2-\bar{y} 1)$ and the environmental difference was obtained by $(\overline{\mathrm{y}} \mathrm{c} 2-\overline{\mathrm{y}} \mathrm{c} 1)$. Thus, genetic gain estimate was obtained by subtracting the environmental difference from the gross difference (Vencovsky et al., 1988).

Subsequently, the genetic progress balance was determined using the method of generalized least squares, as described by Cruz (2001). The average genetic gain $(\mu \hat{G} g)$ for a period was obtained in $\mathrm{kg} \cdot \mathrm{ha}^{-1}$.year ${ }^{-1}$ for grain yield and in $\mathrm{kg} \cdot 100 \mathrm{~L}^{-1} \cdot$ year $^{-1}$ for hectoliter weight. The percentage of annual genetic progress was calculated by the formula $\left(\frac{\mu G g^{\prime}}{\bar{y} 1}\right)$. For statistical analysis, Microsoft Office Excel application and Genes software (Cruz, 2013) were used.

\section{RESULTS AND DISCUSSION}

Evaluation trials of oat cultivars assessed during an eight-year period in the State of RS (Table 2) exhibited a balanced distribution among cultivars with and without fungicide use on aerial plant parts. Mainly, they presented proper balance with respect to the locations of trials installation, highlighting the trials carried out in Eldorado do Sul, Pelotas, and Três de Maio with and without fungicide, and in Passo Fundo without fungicide. Moreover, these trials were present in all evaluation years with good annual representation of the locations, which presented minimal variation of the five locations and maximum variation of the seven locations during the study period. However, the same balance was not observed in the study regarding genetic progress in irrigated rice in the State of Minas Gerais, where among the four study locations, none was present in all evaluation years and the variation of trial locations per year was one to four trial locations (DoVale et al., 2012). Therefore, it can be inferred that the database was suitable to evaluate genetic progress in oat during this period.

Means of I (13.6\%), D (7.5\%), and R rates (14.8\%) of cultivars during the period from 2007 to 2014 were relatively lower than the M rate (78.8\%) (Table 3). The M rate of oat cultivars was elevated in comparison to the values found in genetic progress studies in wheat with 52\% (Cargnin et al., 2008) and rice with 58\% (DoVale et al., 2012).

Genetics and Molecular Research 15 (4): gmr15049390 
Table 3. Rates of inclusion, deletion, maintenance, and renewal of cultivars in the network of oat cultivars competition trials (Avena sativa L.) from 2007 to 2014 in Rio Grande do Sul, Brazil.

\begin{tabular}{l|c|c|c|c}
\hline Bienniums & Inclusion (\%) & Deletion (\%) & Maintenance (\%) & Renewal (\%) \\
\hline $2007-2008$ & 7.1 & 0.0 & 92.9 & 7.1 \\
\hline $2008-2009$ & 26.3 & 5.3 & 68.4 & 27.8 \\
\hline $2009-2010$ & 30.8 & 3.8 & 65.4 & 32.0 \\
\hline $2010-2011$ & 19.3 & 19.4 & 61.2 & 24.0 \\
\hline $2011-2012$ & 7.4 & 7.4 & 85.2 & 8.0 \\
\hline $2012-2013$ & 0.0 & 12.0 & 88.0 & 0.0 \\
\hline $2013-2014$ & 4.3 & 4.3 & 91.3 & 4.5 \\
\hline Mean of 8 years & 13.6 & 7.5 & 78.9 & 14.8 \\
\hline
\end{tabular}

In all nine locations (Augusto Pestana, Cruz Alta, Eldorado do Sul, Ijuí, Itaqui, Passo Fundo, Pelotas, Três de Maio, and Vacaria) and years (2007 to 2014) and in the overall RS state, the mean grain yield of the oat cultivars in trials with fungicide use was greater than that of the oat cultivars in trials without fungicide use on aerial plant parts (Table 4). The same behavior was observed for hectoliter weight, except for the locations of Pelotas and Vacaria in 2008 and Passo Fundo in 2012, where the mean hectoliter weight was greater in trials without fungicide use.

Considering all trial locations and years, the overall mean grain yield was $2863.37 \mathrm{~kg} /$ ha with fungicide use and $1941.56 \mathrm{~kg} / \mathrm{ha}$ without fungicide use. The difference in the mean grain yield between trials with and without fungicide use was $921.81 \mathrm{~kg} / \mathrm{ha}$, corresponding to a reduction of $32.19 \%$. Meanwhile, the mean hectoliter weight was $46.79 \mathrm{~kg} / 100 \mathrm{~L}$ with fungicide use and $41.28 \mathrm{~kg} / 100 \mathrm{~L}$ without fungicide use. Thus, the fact of not using the fungicide reduced the hectoliter weight by $11.78 \%$. These results demonstrated that the chemical control application using fungicides helps in the maintenance of yield potential and grain quality.

The reduction in yield potential and industrial quality in oat grown without fungicide use might be linked to the presence of pathogens, environmental conditions favorable to pathogens, and genetic susceptibility of cultivars to the pathogen. Deuner et al. (2014) stated that because oat is the second most cultivated cereal in southern Brazil, an increase in cultivated area increases the risk of epidemics. Some of the most important fungal diseases of oat include leaf rust, stem rust, and Helminthosporium leaf spot, which are caused by Puccinia coronata f. sp avenae, P. graminis f. sp avenae, and Drechslera avenae, respectively. Leaf rust, being the most destructive disease of oat (Chaves and Martinelli, 2005), reduces the quality and yield of grains by approximately $50 \%$. According to Martinelli et al. (2009), the effectiveness of the pathogen-resistance genes in oat is low and the virulence of the races found in southern Brazil is complex. This scenario justifies the efforts in performing trials with and without the use of foliar fungicide in oat.

Oat cultivar trials with and without fungicide use demonstrated satisfactory results, since genetic progress from 2007 to 2014 was greater in trials without fungicide use at all locations (Table 5), except Passo Fundo. Moreover, the same cultivars were evaluated with and without fungicide use, suggesting efficient gene introgressions and gene pyramiding for resistance to the main pathogens in oat. The influence of fungicide use on oat crop has been reported in several adaptability and stability studies. These studies have reported a necessity for the stratification of environments depending on the treatment with or without fungicide; the fungicide use was found to influence the results (Lorencetti et al., 2004; Benin et al., 2005).

Genetics and Molecular Research 15 (4): gmr15049390 
Table 4. Means of grain yield, in $\mathrm{kg} / \mathrm{ha}$, and hectoliter weight, in $\mathrm{kg} / 100 \mathrm{~L}$, with and without fungicide use on the aerial parts of cultivars evaluated in the network of oat cultivars competition trials (Avena sativa L.) during the period from 2007 to 2014 in nine locations (Augusto Pestana, Cruz Alta, Eldorado do Sul, Ijuí, Itaqui, Passo Fundo, Pelotas, Três de Maio, and Vacaria) and in the overall mean of the Rio Grande do Sul (RS) State, Brazil.

\begin{tabular}{|c|c|c|c|c|c|c|c|c|}
\hline Location/State & 2007 & 2008 & 2009 & 2010 & 2011 & 2012 & 2013 & 2014 \\
\hline & \multicolumn{8}{|c|}{ Grain yield with fungicide use $(\mathrm{kg} / \mathrm{ha})$} \\
\hline Augusto Pestana & - & - & - & 2119.08 & 3012.48 & 3961.68 & 3572.59 & 2517.34 \\
\hline Cruz Alta & 1026.85 & 1360.57 & - & - & - & - & - & - \\
\hline Eldorado do Sul & 3080.23 & 4116.00 & 3896.72 & 3570.88 & 4863.56 & 2601.84 & 4196.73 & 3210.97 \\
\hline Ijuí & - & 1622.43 & 2499.94 & - & - & - & - & - \\
\hline Itaqui & - & - & - & - & - & - & 1292.86 & 1292.81 \\
\hline Passo Fundo & 2429.85 & 1719.64 & 3453.72 & 3428.36 & 4072.48 & 1502.88 & - & 2570.15 \\
\hline Pelotas & 1247.92 & 1884.21 & 1591.28 & 2532.04 & 4136.76 & 2455.00 & 2564.45 & 1281.90 \\
\hline Três de Maio & 2604.15 & 3311.64 & 3598.72 & 2204.28 & 2792.44 & 2979.96 & 4491.86 & 2707.00 \\
\hline Vacaria & - & 3899.79 & 4270.83 & - & - & - & - & - \\
\hline \multirow[t]{2}{*}{ Mean (RS) } & 2077.80 & 2559.18 & 3218.54 & 2770.93 & 3775.54 & 2700.27 & 3223.70 & 2263.36 \\
\hline & \multicolumn{8}{|c|}{ Grain yield without fungicide use $(\mathrm{kg} / \mathrm{ha})$} \\
\hline Augusto Pestana & - & - & - & 1508.04 & 2282.04 & 2864.32 & 2236.14 & 1486.20 \\
\hline Cruz Alta & 564.38 & 657.29 & - & - & - & - & - & - \\
\hline Eldorado do Sul & 1906.77 & 1826.79 & 3367.39 & 2016.84 & 3374.00 & 1864.08 & 3208.36 & 1648.76 \\
\hline Ijuí & - & 544.36 & 1764.06 & - & - & - & - & - \\
\hline Itaqui & - & - & - & - & - & - & 1172.68 & 1172.77 \\
\hline Passo Fundo & 1704.31 & 762.64 & 2362.67 & 2429.88 & 3185.08 & 1427.00 & 2090.55 & 1308.96 \\
\hline Pelotas & 528.85 & 850.86 & 1494.83 & 1712.04 & 3201.64 & 1142.12 & 1985.41 & 783.19 \\
\hline Três de Maio & 1772.23 & 1660.21 & 3201.83 & 1797.24 & 1549.96 & 1836.80 & 3259.41 & 1591.14 \\
\hline Vacaria & - & 2741.29 & 2724.61 & - & - & - & - & -- \\
\hline \multirow[t]{2}{*}{ Mean (RS) } & 1295.31 & 1291.92 & 2485.90 & 1892.81 & 2718.54 & 1826.86 & 2325.42 & 1331.84 \\
\hline & \multicolumn{8}{|c|}{ Hectoliter weight with fungicide use $(\mathrm{kg} / 100 \mathrm{~L})$} \\
\hline Augusto Pestana & - & - & - & 46.46 & 52.10 & 49.60 & 51.64 & 48.31 \\
\hline Cruz Alta & - & - & - & - & - & - & - & - \\
\hline Eldorado do Sul & 53.02 & 53.79 & 52.50 & 54.08 & 49.85 & 43.53 & 52.77 & 52.13 \\
\hline Ijuí & - & 45.40 & 40.67 & - & - & - & - & - \\
\hline Itaqui & - & - & - & - & - & - & 43.05 & 43.05 \\
\hline Passo Fundo & 50.66 & 40.01 & 52.50 & 49.88 & 54.41 & 40.42 & - & 46.64 \\
\hline Pelotas & 48.85 & 34.86 & 46.67 & 45.16 & 54.36 & 51.65 & 51.23 & 46.40 \\
\hline Três de Maio & 40.06 & 43.42 & 39.67 & 36.71 & 44.00 & 44.80 & 47.05 & 27.24 \\
\hline Vacaria & - & 43.82 & 45.33 & - & - & - & - & - \\
\hline \multirow[t]{2}{*}{ Mean (RS) } & 48.15 & 43.55 & 46.22 & 46.46 & 50.94 & 46.00 & 49.15 & 43.96 \\
\hline & \multicolumn{8}{|c|}{ Hectoliter weight without fungicide use $(\mathrm{kg} / 100 \mathrm{~L})$} \\
\hline Augusto Pestana & - & - & - & 40.82 & 49.37 & 43.13 & 45.27 & 44.57 \\
\hline Cruz Alta & - & - & - & - & - & - & - & - \\
\hline Eldorado do Sul & 43.68 & 40.46 & 50.11 & 45.28 & 41.06 & 37.02 & 46.18 & 40.97 \\
\hline Ijuí & - & 36.06 & 33.44 & - & - & - & - & - \\
\hline Itaqui & - & - & - & - & - & - & 42.73 & 42.75 \\
\hline Passo Fundo & 40.21 & 31.23 & 45.00 & 44.40 & 50.28 & 44.17 & 38.86 & 37.58 \\
\hline Pelotas & 33.10 & 44.71 & 44.67 & 39.74 & 51.15 & 41.33 & 46.32 & 37.63 \\
\hline Três de Maio & 34.37 & 33.57 & 37.44 & 33.72 & 37.77 & 38.73 & 43.41 & 23.45 \\
\hline Vacaria & - & 43.89 & 41.56 & - & - & - & - & - \\
\hline Mean (RS) & 37.84 & 38.32 & 42.04 & 40.79 & 45.93 & 40.87 & 43.80 & 37.83 \\
\hline
\end{tabular}

"_." indicates absence of trial.

Genetic progress in grain yield of oat cultivars in the state of RS during the period from 2007 to 2014 was $21.17 \mathrm{~kg} \cdot \mathrm{ha}^{-1} \cdot$ year $^{-1}(1.02 \%$ per year) with fungicide use and 52.12 $\mathrm{kg} \cdot \mathrm{ha}^{-1} \cdot \mathrm{year}^{-1}(4.02 \%$ per year) without fungicide use (Table 5). Meanwhile, the hectoliter weight presented genetic progress of $0.04 \mathrm{~kg} \cdot 100 \mathrm{~L}^{-1} \cdot \mathrm{year}^{-1}(0.08 \%$ per year $)$ with fungicide use and $0.27 \mathrm{~kg} \cdot 100 \mathrm{~L}^{-1} \cdot$ year $^{-1}(0.71 \%$ per year $)$ without fungicide use. Therefore, it can be inferred that genetic progress was superior in trials carried out without fungicide use.

Genetics and Molecular Research 15 (4): gmr15049390 
Table 5. Annual genetic progress and percentage of annual genetic progress in grain yield and hectoliter weight of oat cultivars (Avena sativa L.) calculated in four locations (Eldorado do Sul, Passo Fundo, Pelotas, and Três de Maio) and in the overall Rio Grande do Sul State during 2007 to 2014.

\begin{tabular}{|c|c|c|c|c|}
\hline \multirow[t]{2}{*}{ Location/State } & \multicolumn{2}{|c|}{ Grain yield } & \multicolumn{2}{|c|}{ Hectoliter weight } \\
\hline & $\begin{array}{l}\text { Genetic progress } \\
\left(\mathrm{kg} \cdot \mathrm{ha}^{-1} \cdot \text { year }^{-1}\right)\end{array}$ & $\begin{array}{c}\text { Annual genetic progress } \\
(\%)\end{array}$ & $\begin{array}{l}\text { Genetic progress } \\
\left(\mathrm{kg} \cdot 100 \mathrm{~L}^{-1} \cdot \mathrm{year}^{-1}\right)\end{array}$ & $\begin{array}{c}\text { Annual genetic progress } \\
(\%)\end{array}$ \\
\hline \multicolumn{5}{|l|}{ With fungicide use } \\
\hline Eldorado do Sul & 32.30 & 1.05 & 0.17 & 0.32 \\
\hline Passo Fundo & $86.86^{*}$ & 3.57 & $0.33^{*}$ & 0.65 \\
\hline Pelotas & 1.18 & 0.09 & 0.08 & 0.16 \\
\hline Três de Maio & 18.68 & 0.72 & -0.06 & -0.15 \\
\hline Rio Grande do Sul & 21.17 & 1.02 & 0.04 & 0.08 \\
\hline \multicolumn{5}{|c|}{ Without fungicide use } \\
\hline Eldorado do Sul & 73.96 & 3.88 & 0.56 & 1.28 \\
\hline Passo Fundo & 42.86 & 2.51 & 0.31 & 0.77 \\
\hline Pelotas & 34.68 & 6.56 & 0.14 & 0.42 \\
\hline Três de Maio & 66.48 & 3.75 & 0.28 & 0.81 \\
\hline Rio Grande do Sul & 52.12 & 4.02 & 0.27 & 0.71 \\
\hline
\end{tabular}

*Genetic gain estimated with seven trials in eight years.

The annual genetic progress in grain yield obtained in recent studies with wheat was $0.92 \%$ in Brazil (Beche et al., 2014), 0.67\% in Canada (Thomas and Graf, 2014) and 1.00\% in China (Wu et al., 2014). Similarly, the annual genetic progress in rice was $0.67 \%$ in Brazil (Breseghello et al., 2011); however, no genetic progress was observed in the dry-land rice program of the State of Minas Gerais (Borges et al., 2009). Furthermore, for carioca common bean in the State of Minas Gerais, the annual genetic progress was 6.74\% (Barili et al., 2016). However, in oat, no comparative studies could be found.

The results of this study showed that the breeding program strategies are effective in increasing the hectoliter weight of oat. It is important to study genetic progress in hectoliter weight as it is a measure of grain quality (Lângaro and Carvalho, 2014) and considered a selection criterion in oat breeding programs in southern Brazil (Federizzi et al., 2005). During 1957 to 1996, Barbosa Neto et al. (2000) reported an annual genetic progress of $0.3 \%$ in the hectoliter weight of oat.

Pathogen attack, increase in foliar diseases, and action of hormones, such as ethylene, lead to elevated energy spending and leaf senescence as defense strategies in plants (Taiz and Zeiger, 2013). The lower leaf area resulting from the higher rate of leaf senescence rate can explain the greater genetic progress in trials without fungicide use. In trials without fungicide use, the new cultivars suffer less damaging effect on their vegetative growth upon introduction of major pathogen-resistant genes in them. The reduction in growth due to reduced leaf area was observed in species of the same family as wheat (Triticum aestivum L.). An increase in artificial defoliation rate has been found to result in progressive reduction of grain yield and hectoliter weight of wheat (Souza et al., 2013).

Genetic progress from 2007 to 2014 differed among the four individually studied locations (Eldorado do Sul, Passo Fundo, Pelotas, and Três de Maio). The highest annual genetic progress in grain yield with fungicide use was observed in Passo Fundo (3.57\%) and the lowest in Pelotas $(0.09 \%)$. Meanwhile, opposite grain yield results were obtained in trials without fungicide use, with the highest annual genetic progress in Pelotas $(6.56 \%)$ and the lowest in Passo Fundo (2.51\%) (Table 5). These results can be associated with different climatic conditions in these locations because of the huge difference in the altitudes of Passo Fundo $(687 \mathrm{~m})$ and Pelotas $(13 \mathrm{~m})$. Consequently, in low-altitude environments, the relatively

Genetics and Molecular Research 15 (4): gmr15049390 
higher average air temperature leads to higher growth rate of pathogens. In trials with fungicide use, the lowest annual genetic progress in the hectoliter weight was found in Três de Maio with $-0.15 \%$, followed by Pelotas with $0.16 \%$ and Eldorado do Sul with $0.32 \%$, and the highest in Passo Fundo with $0.65 \%$. Meanwhile, in trials without fungicide use, the annual genetic progress in the hectoliter weight oscillated between $0.42 \%$ in Pelotas and $1.28 \%$ in Eldorado do Sul (Table 5).

In Italy, genetic progress in oat differed among the studied locations (Redaelli et al., 2008). Furthermore, in China, genetic progress in wheat varied depending on the growing region, and the researchers suggested reformulating the breeding programs strategies for regions with low genetic progress rates (Wu et al., 2014).

Studies similar to the present study can be performed in other crops that use comparative trials with and without fungicide use. The differentiation in trials with and without fungicide use was also observed in wheat, which showed higher genetic progress in trials without fungicide, indicating that breeding programs aimed at releasing disease-resistant cultivars present additive effects on grain yield (Oury et al., 2012).

\section{CONCLUSION}

The annual genetic progress in oat grain yield was $1.02 \%$ with fungicide use and $4.02 \%$ without fungicide use during the eight-year study period in RS. Regarding the hectoliter weight, the annual genetic progress was $0.08 \%$ for trials with fungicide use and $0.71 \%$ for trials without fungicide use. Performing network yield trials with and without fungicide use on aerial plant parts is feasible to evaluate the efficiency of oat breeding programs aimed at introducing disease-resistance genes in the released cultivars.

\section{Conflicts of interest}

The authors have no conflict of interest to declare.

\section{ACKNOWLEDGMENTS}

We thank Conselho Nacional de Desenvolvimento Científico e Tecnológico (CNPq) for the productivity research grant and Coordenação de Aperfeiçoamento de Pessoal de Nível Superior (CAPES) for granting scholarships. We also thank the researchers from public and private institutions for participation in oat cultivar competition trials.

\section{REFERENCES}

Barbosa Neto JF, Matiello RR, Carvalho FIF, Oliveira JMS, et al. (2000). Progresso genético no melhoramento da aveiabranca no sul do Brasil. Pesq. Agropec. Bras. 35: 1605-1612. http://dx.doi.org/10.1590/S0100-204X2000000800013

Beche E, Benin G, Silva CL, Munaro LB, et al. (2014). Genetic gain in yield and changes associated with physiological traits in Brazilian wheat during the 20th century. Eur. J. Agron. 61: 49-59. http://dx.doi.org/10.1016/j.eja.2014.08.005

Benin G, Carvalho FIF, Oliveira AC, Lorencetti C, et al. (2005). Adaptabilidade e estabilidade em aveia em ambientes estratificados. Cienc. Rural 35: 295-302. http://dx.doi.org/10.1590/S0103-84782005000200008

Borges V, Soares AA, Resende MDV, Reis MS, et al. (2009). Progresso genético do programa de melhoramento de arroz de terras altas de minas gerais utilizando modelos mistos. Rev. Bras. Biol. 27: 478-490.

Breseghello F, Morais OP, Pinheiro PV, Silva ACS, et al. (2011). Results of 25 years of upland rice breeding in Brazil. Crop Sci. 51: 914-923. http://dx.doi.org/10.2135/cropsci2010.06.0325

Breseghello F, Rangel PHN and Morais OP (1999). Ganho de produtividade pelo melhoramento genético do arroz irrigado no Nordeste do Brasil. Pesq. Agropec. Bras. 34: 399-407. http://dx.doi.org/10.1590/S0100-204X1999000300011

Genetics and Molecular Research 15 (4): gmr15049390 
Cargnin A, Souza MA and Fronza V (2008). Progress in breeding of irrigated wheat for the cerrado region of Brazil. Crop Breed. Appl. Biotechnol. 8: 39-46. http://dx.doi.org/10.12702/1984-7033.v08n01a06

Chaves MS and Martinelli JA (2005). Ferrugem da folha da aveia: aspectos epidemiológicos e perspectivas de controle através da resistência genética na região sul do Brasil.Rev. Bras. Agrocienc 11: 397-403.

Conab (2013). Acompanhamento da safra brasileira. Available at [http://www.conab.gov.br/OlalaCMS/uploads/ arquivos/13_09_10_16_05_53_boletim_portugues_setembro_2013.pdf]. Accessed August 30, 2016.

Cruz CD (2001). Programa genes: versão Windows; aplicativo computacional em genética e estatística. 1st edn. Editora UFV, Viçosa.

Cruz CD (2013). Genes - a software package for analysis in experimental statistics and quantitative genetics. Acta Sci. Agron. 35: 271-276. http://dx.doi.org/10.4025/actasciagron.v35i3.21251

Deuner CC, Martinelli JA, Boller W and Schons J (2014). Manejo de doenças. In: Lângaro NC and Carvalho IQ (org.) Indicações técnicas para a cultura da aveia: XXXIV Reunião da comissão brasileira de pesquisa de aveia. 1st edn. Editora UPF, Passo Fundo.

Doehlert DC, McMullen MS and Hammond JJ (2001). Genotypic and environmental effects on grain yield and quality of oat grown in North Dakota. Crop Sci. 41: 1066-1072. http://dx.doi.org/10.2135/cropsci2001.4141066x

DoVale JC, Soares PC, Cornélio VMO, Reis MS, et al. (2012). Contribuição genética na produtividade do arroz irrigado em minas gerais no período de 1998 a 2010. Bragantia 71: 460-466. http://dx.doi.org/10.1590/S0006$\underline{87052012000400002}$

Faria AP, Fonseca Júnior NS, Destro D and Faria RT (2007). Ganho genético na cultura da soja. Semin. Cienc. Agrar. 28: 71-78. http://dx.doi.org/10.5433/1679-0359.2007v28n1p71

Federizzi LC, Milach SCK, Pacheco MT, Barbosa Neto JF, et al. (2005). Melhoramento da aveia. In: Borém, A. Melhoramento de espécies cultivadas. 2nd edn. Editora UFV, Viçosa.

Lângaro NC and Carvalho IQ (2014). Indicações técnicas para a cultura da aveia: XXXIV Reunião da comissão brasileira de pesquisa de aveia. 1st edn. Editora UPF, Passo Fundo.

Lorencetti C, Carvalho FIF, Marchioro VS, Benin G, et al. (2004). Implicações da aplicação de fungicida na adaptabilidade e estabilidade de rendimento de grãos em aveia branca. Cienc. Rural 34: 693-700. http://dx.doi.org/10.1590/S0103$\underline{84782004000300007}$

Luche HS, Nornberg R, Crestani M, Ribeiro G, et al. (2013). Parâmetros de adaptabilidade e estabilidade em cultivares brasileiras e estrangeiras de aveia branca. Curr. Agric. Sci. Tech 19: 31-40.

Martinelli JA, Chaves MS, Federizzi LC and Savi V (2009). Expressão da resistência parcial à ferrugem da folha da aveia presente na linhagem MN841801, no ambiente do sul do brasil. Cienc. Rural 39: 1335-1342. http://dx.doi. org/10.1590/S0103-84782009005000097

Nedel JL (1994). Progresso genético no rendimento de grãos de cultivares de trigo lançadas para cultivo entre 1940 e 1992. Pesq. Agropec. Bras. 29: 1565-1570.

Oury FX, Godin C, Mailliard A, Chassin A, et al. (2012). A study of genetic progress due to selection reveals a negative effect of climate change on bread wheat yield in France. Eur. J. Agron. 40: 28-38. http://dx.doi.org/10.1016/j. eja.2012.02.007

RCBPA (2008). Resultados experimentais da XXVIII Reunião da Comissão Brasileira de Pesquisa de Aveia. Universidade Federal de Pelotas, Pelotas.

RCBPA (2009). Resultados experimentais da XXIX Reunião da Comissão Brasileira de Pesquisa de Aveia. Universidade Federal do Rio Grande do Sul, Porto Alegre.

RCBPA (2010). Resultados experimentais da XXX Reunião da Comissão Brasileira de Pesquisa de Aveia. Embrapa Pecuária Sudeste. São Carlos.

RCBPA (2011). Resultados experimentais da XXXI Reunião da Comissão Brasileira de Pesquisa de Aveia. Universidade de Passo Fundo. Passo Fundo.

RCBPA (2012). Resultados experimentais da XXXII Reunião da Comissão Brasileira de Pesquisa de Aveia. Embrapa Trigo. Passo Fundo.

RCBPA (2013). Resultados experimentais da XXXIII Reunião da Comissão Brasileira de Pesquisa de Aveia. Universidade Federal de Pelotas. Pelotas.

RCBPA (2014). Resultados experimentais da XXXIV Reunião da Comissão Brasileira de Pesquisa de Aveia. Fundação ABC. Castro.

RCBPA (2015). Resultados experimentais da XXXV Reunião da Comissão Brasileira de Pesquisa de Aveia. Universidade Federal do Rio Grande do Sul, Porto Alegre.

Redaelli R, Laganà P, Rizza F, Nicosia OLD, et al. (2008). Genetic progress of oats in Italy. Euphytica 164: 679-687. http://dx.doi.org/10.1007/s10681-008-9680-y

Genetics and Molecular Research 15 (4): gmr15049390 
Ribeiro RM, do Amaral Júnior AT, Gonçalves LSA, Candido LS, et al. (2012). Genetic progress in the UNB-2U population of popcorn under recurrent selection in Rio de Janeiro, Brazil. Genet. Mol. Res. 11: 1417-1423. http:// dx.doi.org/10.4238/2012.May.15.12

Rodrigues O, Lhamby JCB, Didonet AD and Marchese JA (2007). Fifty years of wheat breeding in Southern Brazil: yield improvement and associated changes. Pesq. Agropec. Bras. 42: 817-825. http://dx.doi.org/10.1590/S0100204X2007000600008

Souza VQ, Nardino M, Bonato GO, Bahry CA, et al. (2013). Desfolha em diferentes estádios fenológicos sobre características agronômicas em trigo. Biosci. J. 29: 1905-1911.

Taiz L and Zeiger E (2013). Fisiologia vegetal. 5th edn. Editora Artmed, Porto Alegre.

Thomas JB and Graf RJ (2014). Rates of yield gain of hard red spring wheat in western Canada. Can. J. Plant Sci. 94: 1-13. http://dx.doi.org/10.4141/cjps2013-160

Toledo JFF, Almeida LA, Kiihl RAS and Menosso OG (1990). Ganho genético em soja no estado do Paraná, via melhoramento. Pesq. Agropec. Bras. 25: 89-94.

Vencovsky R, Morais AR, Garcia JC and Teixeira NM (1988). Progresso genético em vinte anos de melhoramento do milho no Brasil. In: Congresso nacional de milho e sorgo, Belo Horizonte. Anais... Sete Lagoas, EMBRAPA: CNPMS 16: 300-307.

Wu W, Li C, Ma B, Shah F, et al. (2014). Genetic progress in wheat yield and associated traits in China since 1945 and future prospects. Euphytica 196: 155-168.

Zambonato F, Federizzi LC, Pacheco MT, Arruda MP, et al. (2012). Phenotypic and genetic characterization of partial resistance to crown rust in Avena sativa L. Crop Breed. Appl. Biotech. 12: 261-268.

Genetics and Molecular Research 15 (4): gmr15049390 